\title{
RANCANG BANGUN APLIKASI SISTEM UJIAN SARINGAN MASUK SMA BERBASIS ANDROID (Studi Kasus SMA Amir Hamzah Medan)
}

\author{
Audina L Sitanggang, Mentari Hati Loi, Evta Indra* \\ Program Studi Sistem Informasi Fakultas Teknologi dan Ilmu Komputer Universitas Prima Indonesia \\ E-mail:"evtaindra@unprimdn.ac.id
}

\begin{abstract}
ABSTRAK - Era globalisasi teknologi komputer saat ini banyak digunakan oleh perusahaan dan bahkan lembaga pendidikan. Pada lembaga pendidikan, teknologi dapat meningkatkan kualitas dari siswa. Salah satunya adalah dalam pelaksanaan ujian masuk. Ujian saringan masuk merupakan kegitan yang dilakukan oleh sekolah untuk menyeleksi calon siswa baru. Dalam dunia pendidikan ujian dimaksudkan untuk mengukur taraf pencapaian suatu tujuan pengajaran oleh siswa sebagai peserta didik, sehingga siswa dapat mengetahui tingkat kemampuannya. Saat ini ujian saringan masuk pada SMA masih dilakukan dengan sistem ujian tertulis. Sistem ujian seperti ini tentunya memiliki kekurangan seperti pemborosan kertas dan dalam pelaksanaannya juga membutuhkan pengawasan yang ketat terhadap siswa yang melakukan kecurangan saat ujian, serta tenaga khusus untuk pengoreksian lembar jawaban dan membuat skor hasil tes ujian. Sistem ujian saringan masuk berbasis Android ini dapat memberikan solusi yaitu dengan memfasilitasi sekolah untuk melakukan koreksi dan pengawasan selama ujian, dan hasilnya efektif dan efisien dalam mengelola, mendistribusikan dan mengelola hasil data ujian. Aplikasi di bangun dengan menggunakan metode pengembangan aplikasi pemograman android dan aplikasi hybrid yaitu mengimplementasikan HTML,CSS, Javascript dan Java. dari hasil analisis pendapat terhadap aplikasi ujian saringan masuk berbasis android ini, responden dengan sangat suka sebanyak 5\%, persentase tidak suka10\%, persentasi sangat tidak suka sebanyak 7\% dan responden suka sebanyak $78 \%$, jadi Pada persentasi tertinggi terdapat pada pilihan suka sebanyak 78\% sehingga bisa disimpulkan bahwa Aplikasi Ujian Saringan Masuk Berbasis android ini memenuhi tujuan dari di rancangnya aplikasi tersebut.

Keywords: Ujian Saringan masuk, SMA, Web, Mobile, Android
\end{abstract}

\section{PENDAHULUAN}

Era globalisasi dengan kemajuan teknologi saat ini banyak dimanfaatkan oleh perusahaan bahkan institusi pendidikan juga. Dalam institusi pendidikan pemanfaatan teknologi saat ini salah satunya untuk mendapatkan taraf kuantitas calon peserta didik. Penggunaan tekologi saat ini terutama berbasis android dapat diterapkan dalam sistem ujian. Salah satunya dalam pelaksanaan ujian saringan masuk. Ujian saringan masuk merupakan kegitan yang dilakukan oleh sekolah untuk menyeleksi calon siswa baru[1],[13]. Dalam dunia pendidikan ujian dimaksudkan untuk mengukur taraf pencapaian suatu tujuan pengajaran oleh siswa sebagai peserta didik, sehingga siswa dapat mengetahui tingkat kemampuannya. Saat ini ujian saringan masuk pada SMA masih dilakukan dengan sistem ujian tertulis.

Sistem ujian seperti ini tentunya memiliki kekurangan seperti pemborosan kertas dan dalam pelaksanaannya juga membutuhkan pengawasan yang ketat terhadap siswa yang melakukan kecurangan saat ujian, serta tenaga khusus untuk pengoreksian lembar jawaban dan membuat skor hasil tes ujian. Salah satu upaya untuk memperbaiki proses penerimaan siswa baru dan meningkatkan pelayanan kepada calon siswa, maka dibutuhkan sebuah sistem yang dapat melakukan proses penerimaan siswa baru yang tidak dibatasi oleh ruang dan waktu.Saat ini pada SMA Amir Hamzah dalam melakukan ujian saringan masuk penerimaan siswa baru masih dengan sistem tertulis. Hal ini masih menjadi hal yang merepotkan bagi sekolah tersebut karena sistem yang masih tertulis itu membuat sekolah harus melakukan proses ujian dengan sangat teliti mulai dari pengawasan terhadap siswa yang sedang ujian bisa saja melakukan kecurangan, selain itu juga pemborosan terhadap penggunaan kertas, pengecekan kertas ujian serta penjumlahan nilai yang masih dilakukan secara manual. Hal seperti ini akan membuat ujian tersebut kurang efektif dan efisian.

Berdasarkan hal tersebut sebagai solusi untuk mengatasi hal ini adalah dengan pemanfaatan teknologi smartphone yang saat ini sudah menjadi hal yang umum penggunaannya[19]. Smartphone adalah sebuah perangkat yang bisa diinstal berbagai aplikasi dan menggunakan sistem operasi android. Salah satu kelebihan aplikasi berbasis android adalah pengguna cukup mengunduh dan memasang aplikasi pada smartphone.Aplikasi ujian saringan masuk ini akan dikembamgkan pada sistem operasi berbasis android dan juga aplikasi berbasis web sebagai server nya. Dengan sistem ini diharapkan dapat meminimalisir kecurangan, penghematan waktu serta mempermudah panitia pelaksana ujian dalam pengoreksian hasil dari ujian.

\section{METODE PENELITIAN}

Metodologi penelitian ditunjukkan pada gambar 1 sebagai berikut : 


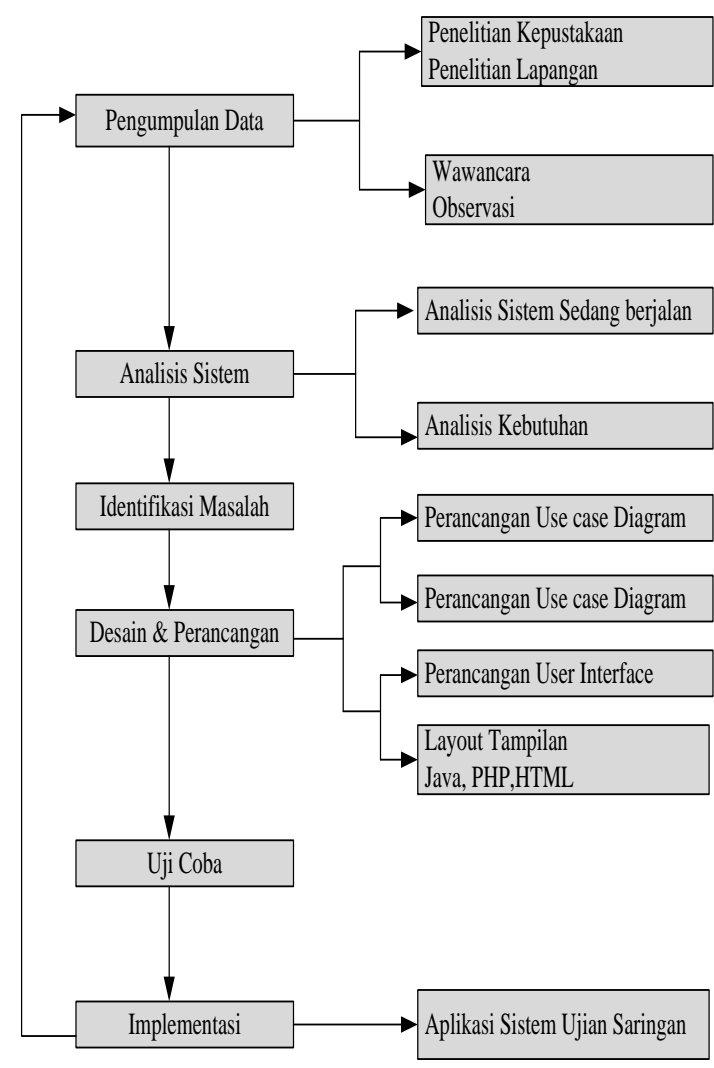

Gambar 1. Metodologi Penelitian

Metode penelitian yang ingin dirancang tersebut pertama yang dilakukan adalah pengumpulan data berdasarkan kebutuhan sistem dari sekolah yang diteliti dengan melakukan penilitian kepustakaan kesekolah atau lapangan, mengobservasi dan wawancara terhadap pihak terkait. Berikutnya analisis sistem yaitu menganalisis sistem yang sedang berjalan pada sekolah tersebut. Perancangan sistem dengan menggunakan use case diagram dan membuat class diagram serta perancangan terhadap skema database. Rancang bangun sistem akan di lakukan dengan sistem operasi berbasis android dan sistem web sebagai server dari sistem tersebut. Sistem akan di uji atau melakukan testing pada aplikasi ujian untuk mengetahui kelayakan dari sistem yang sudah di rancang. Apabila aplikasi sistem ujian saringan masuk tersebut bekerja sesuai dengan kebutuhan maka akan di implementasikan dan digunakan pihak sekolah untuk proses ujian saringan masuk yang akan di laksanakan dan digunakan untuk pengambilan kesimpulan dan pengembangan sistem selanjutnya.

\section{TINJAUAN PUSTAKA}

\subsection{Ujian Saringan Masuk}

Ujian saringan masuk adalah ujian yang diselenggarakan oleh sekolah untuk menyeleksi calon siswa baru yang memenuhi syarat dan menjamin kualitas seorang peserta didik[1]. Ujian saringan masuk yaitu ujian tertulis yang akan diikuti setiap siswa dimana ujian tersebut berguna untuk menentukan kemampuan potensi akademik yang dimiliki oleh setiap calon siswa baru [13].

\subsection{Aplikasi Mobile}

Aplikasi mobile adalah aplikasi yang menggunakan perlengkapan seperti PDA, handphone. Aplikasi mobile ini merupakan aplikasi yang dapat memudahkan kita dalam melakukan berbagai aktifitas seperti hiburan, belajar, browsing dan sebagainya[10-11].

\subsection{Android}

Android adalah sistem operasi mobile yang berkembang saat ini dan berbasi linux kernel yang dirancang untuk perangkat seluler layar sentuh dan komputer tablet. Android yang disebarkan secara open source dan menggunakan bahasa pemograman java berupa java library dengan lisensi apache, free software[17]. Pengembangan aplikasi untuk sistem informasi android dibagi menjadi tiga yaitu pengembangan aplikasi native (java), pengembangan aplikasi web (PHP) dan pengembangan aplikasi hybrid (java + PHP).

\subsection{Arsitektur Android}

Arsitektur android terdiri atas :

1. Application And Widgets adalah layer yang berhubungan dengan aplikasi saja, misalnya kita mendownload aplikasi kemudian aplikasi diinstal dan dijalankan.

2. Aplikasi frameworks merupakan open development platform dimana para pembuat aplikasi mengembangkan sistem operasi android dimana pengembang memiliki akses pada API frameworks. Di layer inilah aplikasi dirancang atau di ciptakan.

3. Libraries merupakan layer dimana fitur-fitur android berada.

4. Android Run Time Bagian ini menyediakan komponen kunci yang disebut Dalvik . Virtual Machine yang merupakan jenis Java Virtual Machine yang dirancang khusus dan dioptimalkan untuk Android. Android runtime juga menyediakan satu set pustaka inti yang memungkinkan pengembang aplikasi Android untuk menulis aplikasi Android menggunakan bahasa pemrograman Java standar.

5. Linux Kernel merupakan lapisan paling bawah atau paling inti. Lapisan ini menyediakan fusionalitas sitem dasar seperti perlengkapan menajemen kamera, keypad ,tampilan dll[9]. 


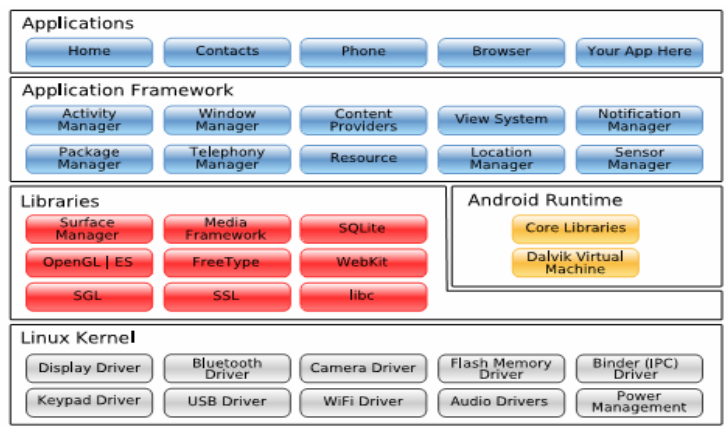

Gambar 2. Arsitektur Android

(Sumber:L. Ashwin Kumar.2012)

\subsection{Android Studio}

Android studio adalah lingkungan pengembangan terpadu integrated development environment (IDE) berbasis Intellij IDEA yang dirilis oleh google. Sebagai platform pendukung untuk windows, mac OS X dan sistem operasi linux. Versi lama dari pengembangan android yaitu eclipse IDE, dan program plug-in yang disebut dengan ADT (Android Development Tools Plugin)[2],[11].

\subsection{Java}

Java adalah bahasa orientasi objek yang merupakan perangkat lunak produksi sun microsystem inc. Java merupakan perangkat lunak pemograman yang multipurpose, multiplatform, mudah dipelajari dan powerful. Java merupakan teknologi untuk membuat dan menjalankan perangkat lunak pada computer standalone ataupun pada lingkungan jaringan. Java memiliki dua program yang berbeda yaitu aplikasi dan applet. Aplikasi merupakan program yang disimpan dan dieksekusi dari komputer lokal sedangkan applet program yang disimpan pada komputer jauh yang dikoneksikan pemakai web browser[15-16]

\subsection{JDK (Java Development Kit)}

JDK sebuah produk yang dikembangkan oleh oracle. JDK merupakan kompiler dan interpreter program java. JDK berisi paket java run time yang komplit atau private run time. JDK terlebih dahulu di instal supaya dapat mengompilasi aplikasi android. [7],[12].

\subsection{Pemograman PHP}

Bahasa pemograman PHP merupakan bahasa pemograman untuk membangun aplikasi web dinamis yang dapat disisipkan pada skrip html yang selanjutnya akan ditampilkan ke web browser[1]. Kode PHP di sisipkan ke dokumen HTML dan ditafsirkan oleh web server dengan php modul prosesor yang akan menghasilkan halaman web dokumen[18].

\subsection{MYSQL}

\begin{tabular}{ccccr}
\multicolumn{2}{c}{ MYSQL adalah } & program & perangkat lunak \\
database & server & multi & user & dan
\end{tabular} menggunakanperintah standar SQL dikembangkan untuk membantu user dalam menyimpan dan menrima data-data dengan cepat. Umumnya $M Y S Q L$ digunakan dengan php untuk membuat sistem server dinamis[1].

\subsection{Sqlite}

Sqlite merupakan system management untuk penyimpanan data yang relasional. Sqlite bersifat publick domain. Sqilte merupakan database yang tertanam di android[12],[16].

\subsection{Uml}

Uml adalah bahasa pemodelan yang digunakan untuk pengembangan software dan dapat membantu pengembang dalam menentukan, visualisasi, dan memodelkan suatu sistem atau perangkat lunak berorientasi objek[10],[12].

\subsection{Use case Diagram}

Use case diagram merupakan fungsionalitas yang tesedia dalam sistem sebagai unit-unit yang menggambarkan bagaimana interaksi antara user dengan sebuah sistem yang digunakan. Use case dilambangkan dengan gambar orang yang disebut dengan aktor dan setiap use case memberikan nilai pada setiap aktor[12-13].

\subsection{Diagram Class}

Class diagram digunakan untuk menggambarkan relasi - relasi yang terdapat dalam sistem atau perangkat lunak. Diagram class merupakan diagram yang mendeskripsikan class, objek dan hubungan antar objek seperti containment, pewarisan, asosoasi dan lain sebagainya. Diagram class dapat didefenisikan diantaranya nama kelas, anggota kelas atau atribut kelas dan operasi-operasi dari sebuah kelas juga garis antar kelas mendefinisikansetiap hubungan komunikasi antar kelas[10].

\subsection{Activity Diagram}

Activity diagram adalah diagram yang mirip dengan flowchart untuk menggambarkan satu alir aktivitas sistem ke alir aktivitas lain yang akan dirancang dan membantu memahami keseluruhan proses pada sistem [10],[13].

\section{HASIL DAN PEMBAHASAN}

\subsection{Gambaran Umum Sistem}

Gambaran umum Rancang Bangun Aplikasi Ujian Saringan Masuk SMA Berbasis Android dapat dilihat pada Gambar 3 berikut : 


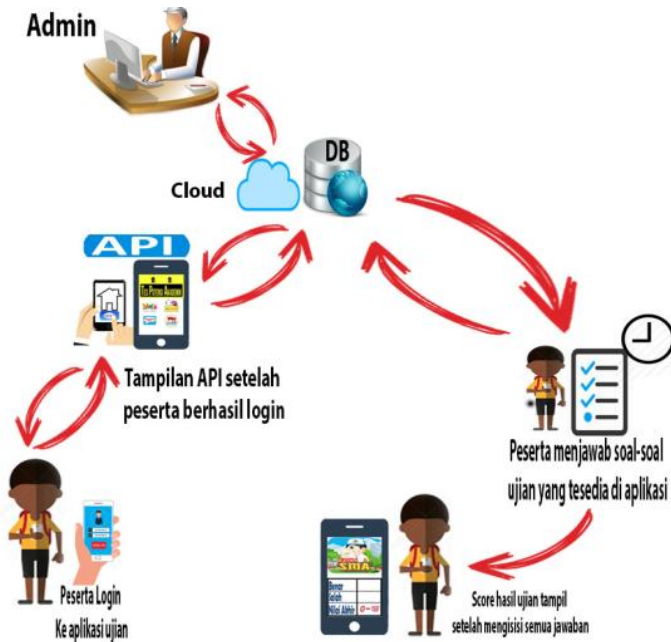

Gambar 3. Gambaran Umum Sistem

Dari gambaran umun sistem diatas peserta menggunakan android dan login ke aplikasi ujian saringan masuk, peserta yang berhasil login akan muncul tampilan API dari aplikasi ujian saringan masuk dan memilih mata pelajaran yang tersedia yang sudah terhubung dengan cloud dan database. Admin akan melakukan cross check atau update pada aplikasi ujian saringan masuk yang terhubung dengan cloud dan database. Peserta mengerjakan soal dengan waktu yang sudah ditentukan. Hasil akhir akan muncul apabila peserta ujian selesai mengerjakan soal.

\subsection{Perancangan Database}

Rancangan database ini berisi relasi antara tabel yang saling berkaitan pada Rancang Bangun Aplikasi Ujian Saringan Masuk Berbasis Android. tampilan seperti pada gambar berikut :

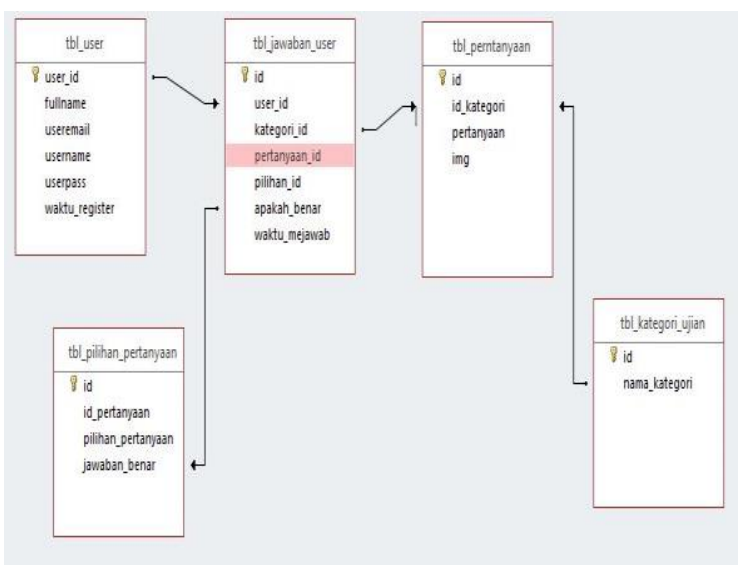

Gambar 5. Rancangan Database

\subsection{Perancangan Use Case Diagram}

Perancangan use case diagram yaitu untuk menggambarkan apa yang dilakukan sistem dan siapa yang berinteraksi dengan sistem. Pemodelan Rancang Bangun Aplikasi Ujian Saringan Masuk Berbasis Android menggunakan Use case diagram. Use case diagram merupakan penjabaran dari Actors dan kebutuhan fungsi use case yang diperlukan di dalam sistem.

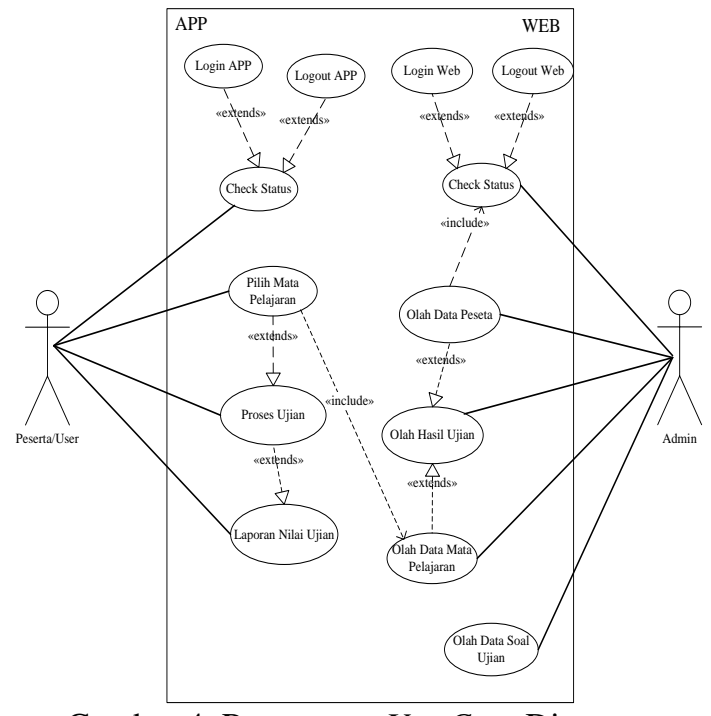

Gambar 4. Rancangan Use Case Diagram

Sistem memiliki dua actors yaitu admin yang mempunyai hak akses untuk melakukan input, update soal, delete ujian, manage soal, jawaban, nilai dan data user, sedangkan user dapat melakukan pilih mata pelajaran, mulai ujian dan selesai ujian.

\subsection{Pemodelan Activity Diagram Aplikasi}

Activity diagram yamg memodelkan alur dari sistem. Activity diagram juga bermanfaat untuk menggambarkan interaksi beberapa use case. Dibawah ini merupakan activity diagram dari rancang bangun aplikasi ujian saringan masuk sma berbasis android.

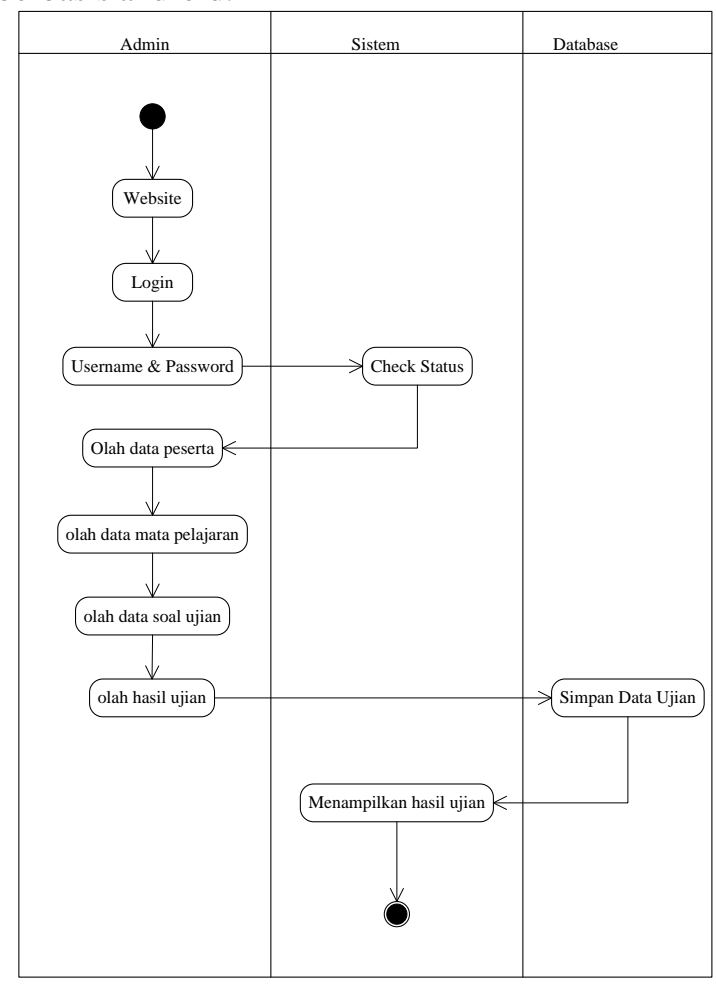

Gambar 6. Activity Diagram Admin 
Activity diagram admin yaitu admin melakukan login website. Admin melakukan check status pada setiap aktifitas ujian saringan masuk seperti mengolah data peserta ujian, mengolah soal ujian dan hasil ujian yang dilakukan oleh peserta.

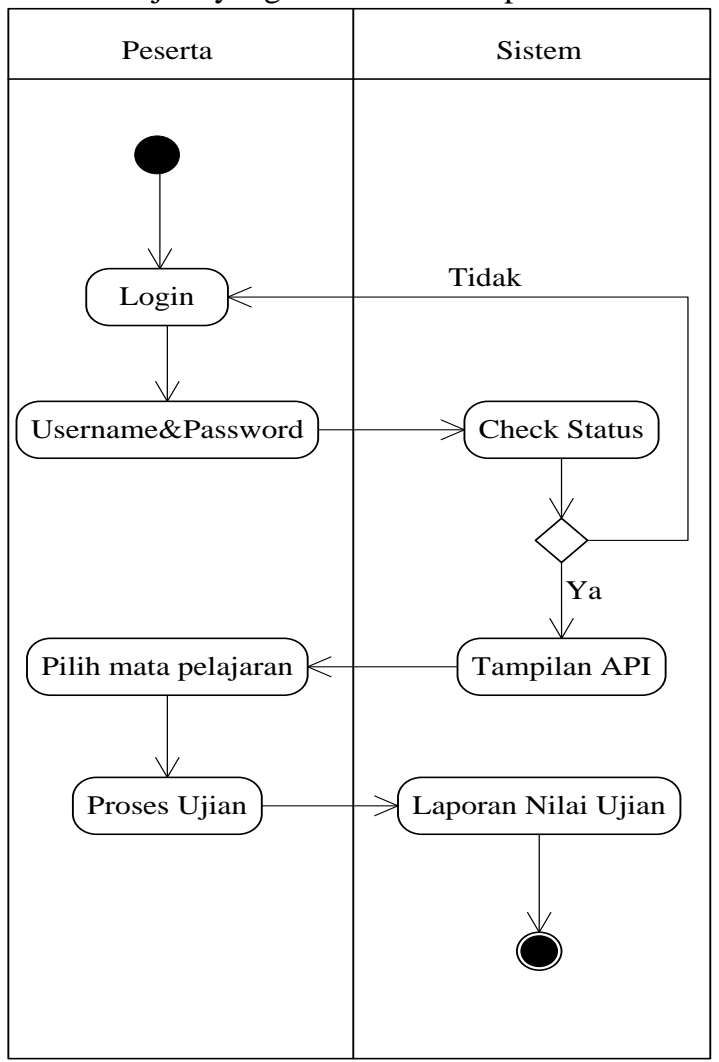

Gambar 7. Activity Diagram Peserta Ujian

Activity diagram peserta ujian yaitu peserta melakukan login dengan aplikasi ujian saringan masuk berbasis android melalui smartphone, sistem akan melakukan check status damana peserta yang berhasil login dapat mengikuti ujian dan megerjakan setiap kategori mata pelajaran.

\subsection{Tampilan Aplikasi}

Adapun tampilan hasil implementasi web Aplikasi ujian saringan masuk SMA adalah sebagai berikut :

1. Tampilan Halaman Login Admin

Halaman ini merupakan halaman login admin untuk masuk ke web server, admin yang berhasil login website akan masuk kehalamn utama,terlihat seperti gambar berikut :

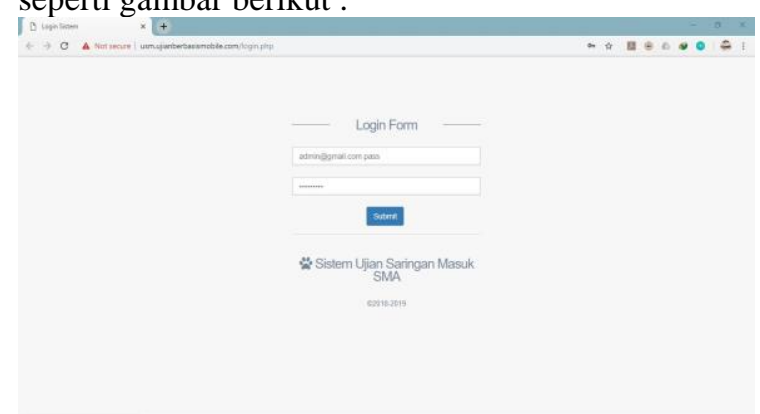

Gambar 8. Tampilan Login Admin
2. Tampilan Halaman Utama Web

Halaman ini merupakan halaman utama yang tampil ketika admin login ke web server, pada halaman ini akan di tampilkan beberapa menu utama.

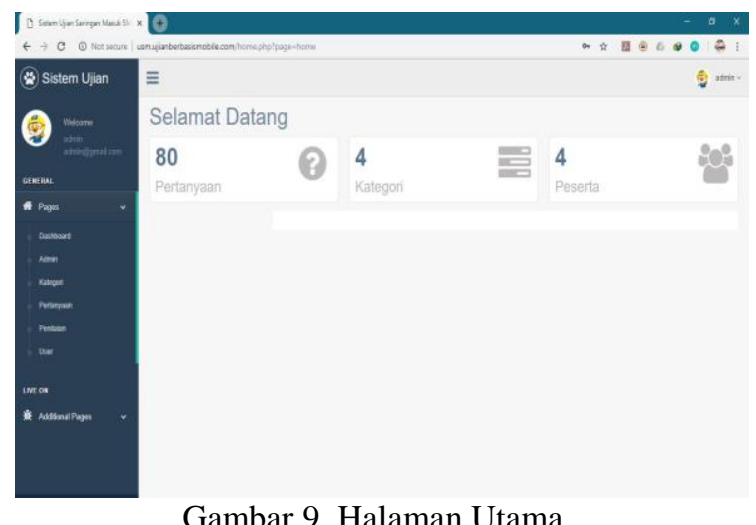

Gambar 9. Halaman Utama

3. Tampilan halaman admin

Halaman tampilan admin ini di khususkan untuk admin.Halaman ini untuk penambahan dan menyimpan data data admin yang bisa login kedalam sistem.

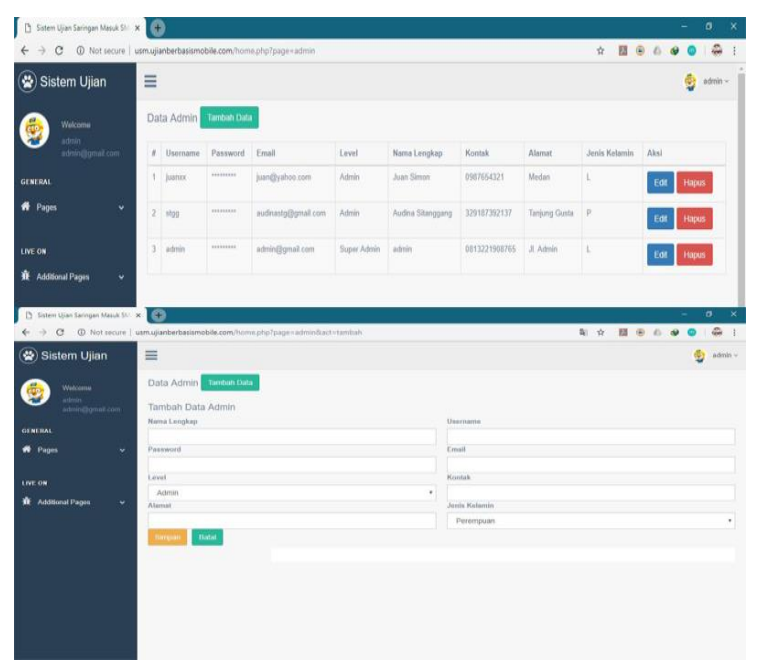

Gamabr 10. Halaman Admin

4. Tampilan Kategori

Halaman kategori adalah halaman yang digunakan oleh admin. Halaman kategori digunakan oleh admin penambahan kategori mata pelajaran yang akan diujiankan, terlihat pada gambar berikut: 


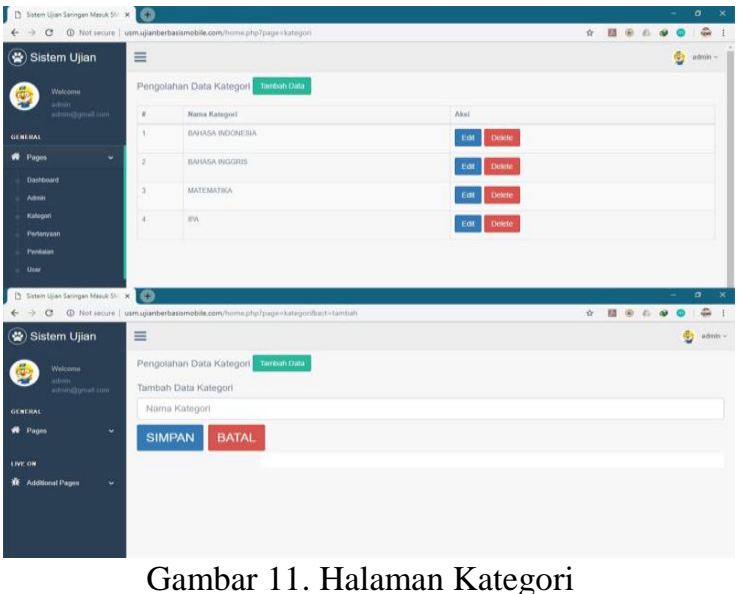

5. Tampilah halaman pertanyaan

Tampilan halaman pertanyaan digunakan untuk menyimpan pertanyaan halaman yang digunakan oleh admin untuk input soal-soal serta pilihan ganda beserta jawaban yang benar dan upload gambar jika sola ujian memiliki gambar, terlihat seperti gambar berikut.

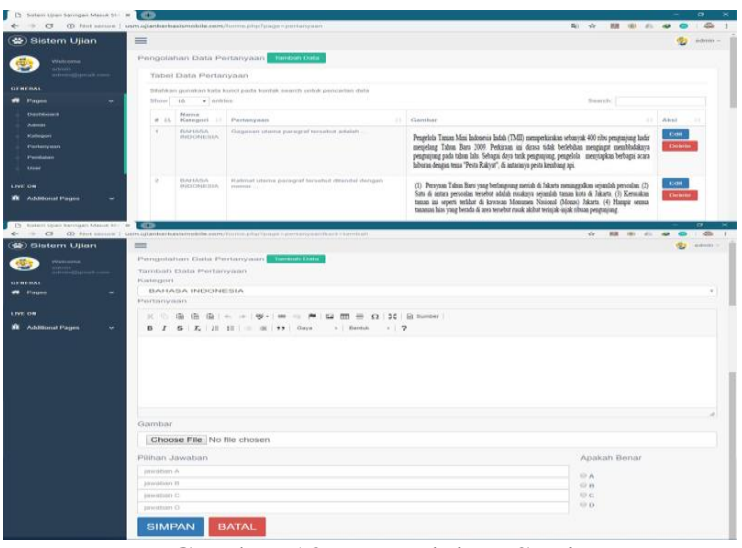

Gambar 12. Pengolahan Soal

6. Halaman Tampilan Pengolahan Nilai

Halaman tampilan nilai merupakan halaman yang dapat digunakan admin untuk menampilkan nilai yang diperoleh oleh peserta ujian.

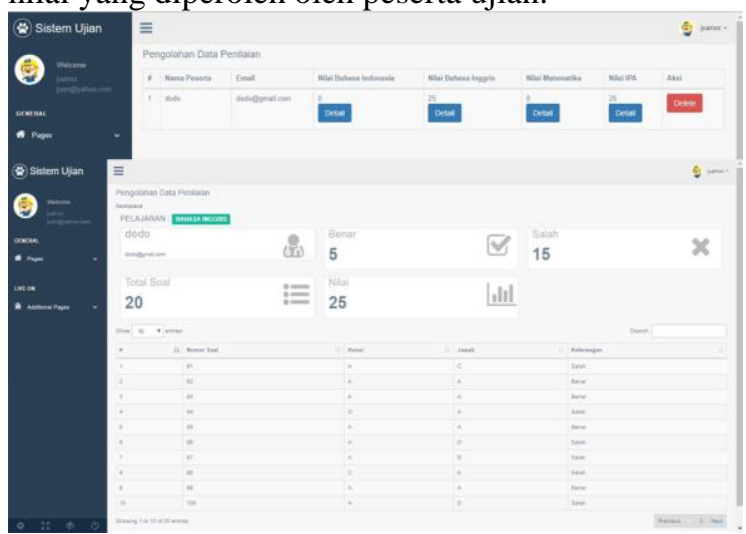

Gambar 13. Data Penilaian
7. Tampilan Halaman Penambahan Peserta Ujian

Pada halaman ini merupakan halaman untuk menampilkan data peserta yang tersimpan dan yang digunakan oleh admin untuk penambahan atau pendaftaran user bagi peserta ujian saringan masuk, terlihat seperti gambar berikut.

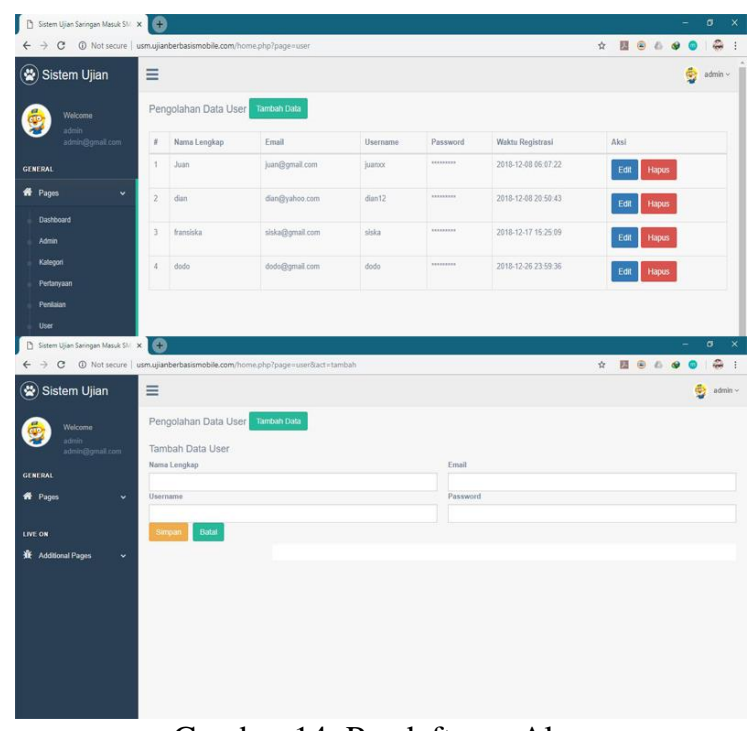

Gambar 14. Pendaftaran Akun

Rancang Bangun Aplikasi Ujian Saringan Masuk Berbasis Android dapat digunakan pada sistem operasi Android minimal versi 4.1 (Jelly Bean). Berikut merupakan tampilan implementasi aplikasi :

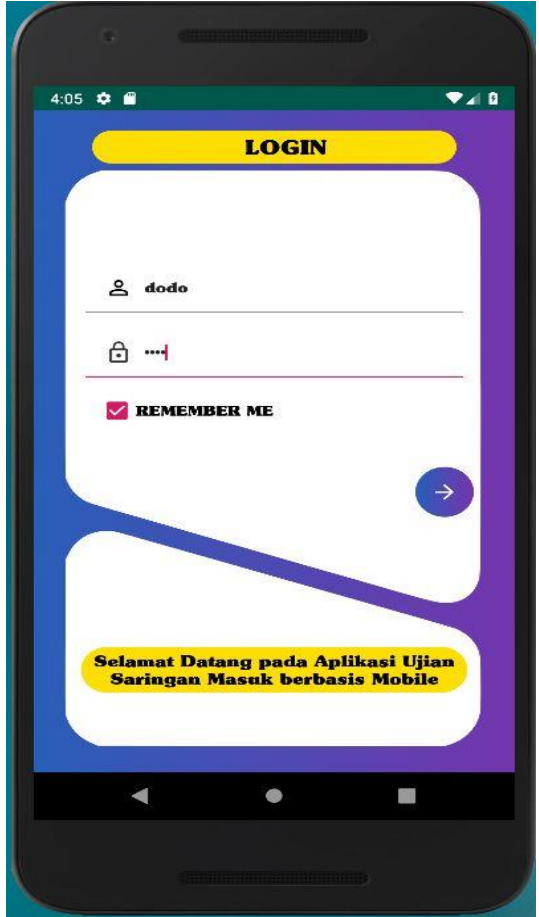

Gambar 15. Login Aplikasi

Gambar diatas merupakan tampilan login peserta untuk mengikuti ujian saringan masuk. 


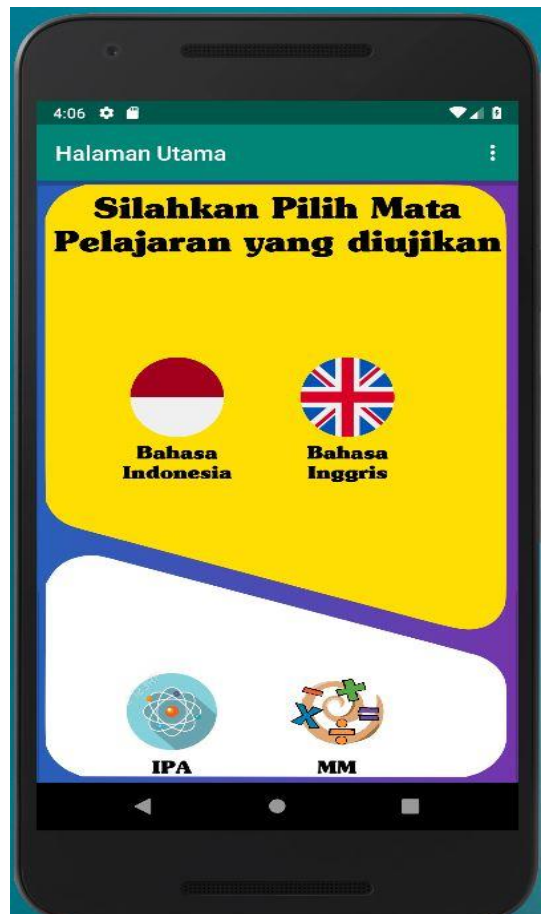

Gambar 16. Halaman Utama Aplikasi

Gambar tersebut merupakn tampilan kategori mata pelajaran yang akan muncul apabila peserta berhasil login aplikasi ujian saringan masuk.

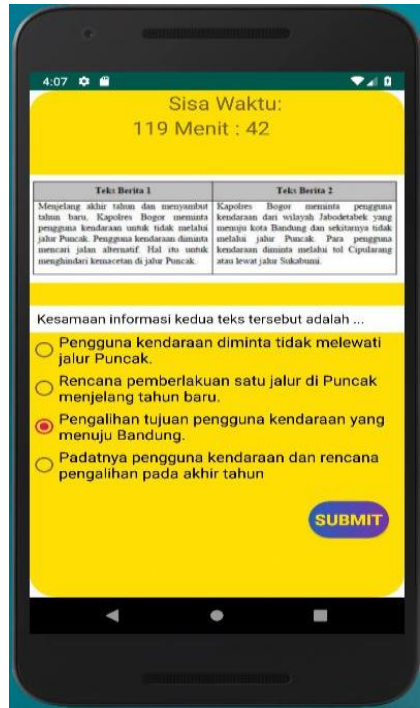

Gambar 17. Tampilan Kategori B.Indonesia

Gambar diatas merupakan tampilan kategori bahasa indonesia apabila peserta memilih kategori bahasa indonesia.

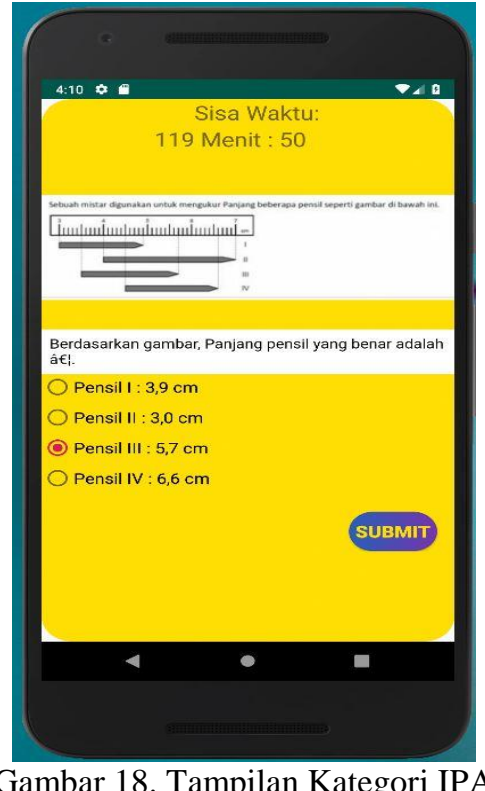

Gambar diatas merupakan tampilan untuk kategori ujian IPA.

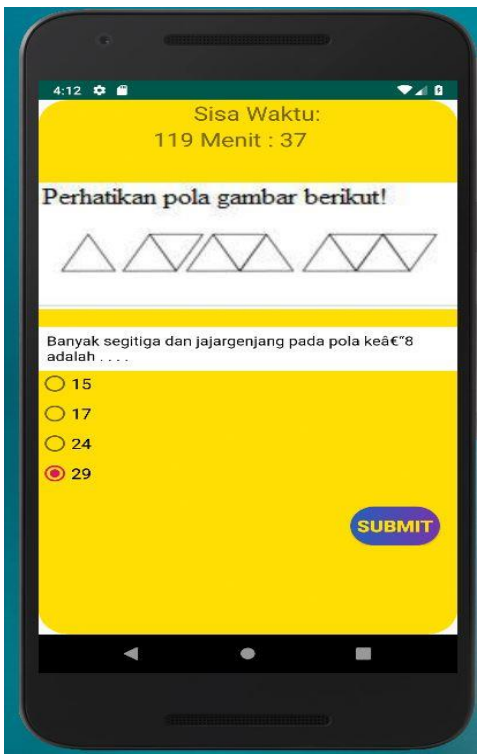

Gambar 19. Tampilan Kategori Matematika

Gambar diatas merupakan tampilan halaman untuk kategori ujian matematika. Dalam aplikasi ujian saringan masuk ini setiap soal ujian memilik empat pilihan jawaban dan hanya salah satu bisa dipilih sebagai jawaban dari soal. Setiap pengerjaan soal yang tersedia pada aplikasi ini memiliki timer yang sudah ditentukan. 


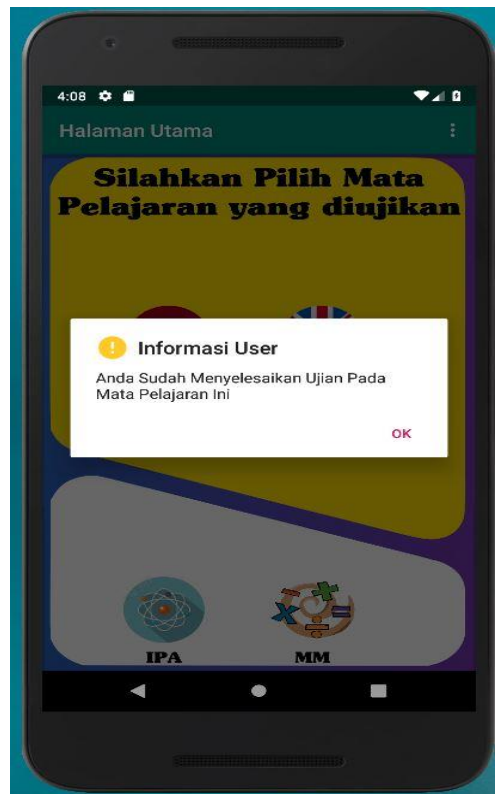

Gambar 20. Informasi Mata pelajaran yang Sudah selesai dikerjakan

Gambar diatas merupakan tampilan dari message box apabila dipilih salah satu kategori ujian yang sudah selesai dikerjakan.

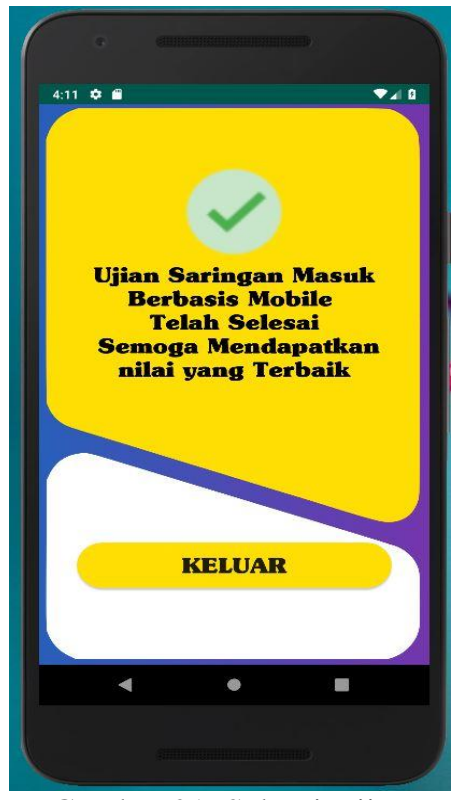

Gambar 21. Selesai Ujian

Gambar diatas tampilan dari aplikasi ujian apabila semua kategori ujian telah selesai di kerjakan. Dan apabila waktu ujian sudah habis maka akn muncul peringatan dan secara otomatis akan kembali ke menu utama.

\subsection{Hasil Analisis Sistem}

Pada diagram analisis pendapat terhadap aplikasi ujian saringan masuk berbasis android ini responden sebagian besar suka dengan aplikasi ini yaitu sebanyak $78 \%$, kemudian responden dengan sangat suka sebanyak $5 \%$, persentase tidak suka $10 \%$ dan persentasi sangat tidak suka sebanyak $7 \%$.

Pada persentasi tertinggi yaitu persentasi pada pilihan suka sebanyak $78 \%$ sehingga bisa disimpulkan bahwa Aplikasi Ujian Saringan Masuk Berbasis android ini memenuhi tujuan dari di rancangnya aplikasi tersebut.

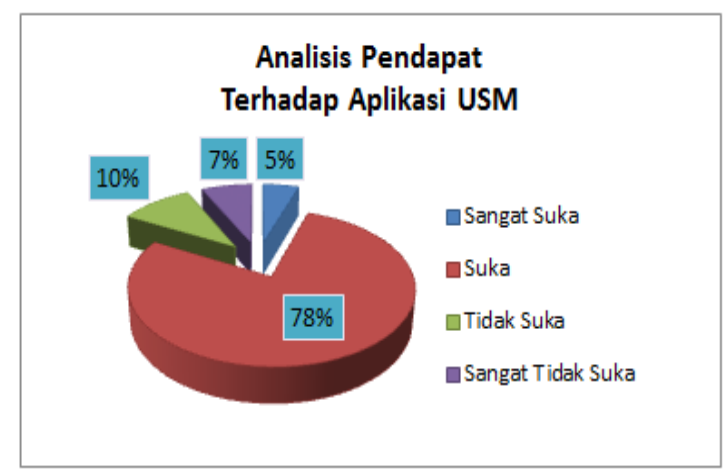

Gambar 22. Grafik Analisis Aplikasi

\subsection{Kelebihan Aplikasi}

Beriukut kelebihan dari aplikasi ujian saringan masuk berbasis android ini :

1. Aplikasi yang berbasis android sehingga bisa di instal di semua perangkat android.

2. Aplikasi dapat dengan mudah digunakan, hanya dengan menyentuh layar jika memilih jawaban soal ujian.

3. Selain untuk digunakan dalam ujian saringan masuk, aplikasi ini juga dapat digunakan untuk pelaksanaan ujian bersama.

4. Karna aplikasi ujian ini terpasang di perangkat android sehingga bisa menghemat dalam penggunaan kertas.

5. Dengan aplikasi ini dapat mengurangi tingkat kecurangan yang dilakukan setiap peserta ujian.

\subsection{Kekurangan Aplikasi}

Aplikasi ujian saringan masuk ini tentunya memiliki kekurangan sebagai berikut :

1. Aplikasi ini membutuhkan ruang memory tambahan karena ukuran dan besaran file cukup besar.

2. Untuk menggunakan aplikasi ini harus terlebih dahulu mendaftar melalui web.

\section{KESIMPULAN}

Dari penelitian yang telah dilakukukan rancang bangun aplikasi ujian saringan masuk ini mengacu pada peraturan ujian yang berlaku di sekolah tersebut. Aplikasi di bangun dengan menggunakan metode pengembangan aplikasi pemograman android dan aplikasi hybrid yaitu mengimplementasikan html,css, javascript dan java. Pemodelan pada sistem dibuat dengan menggunakan bahasa pemodelan UML (unified modeling 
languange) dan perancangan basis data menggunakan PDM (Physical Data Model).

Dalam penggunaan aplikasi ujian saringan masuk ini harus terlebih dahulu mendaftar melalui website ujian saringan masuk untuk mendapatkan username dan password. Apabila sudah terdafdar melalui website, username dan password bisa login dengan menggunakan aplikasi ujian saringan masuk yang sudah terinstal dismartphone pengguna.

\section{UCAPAN TERIMA KASIH}

Penulis mengucapkan terima kasih kepada Universitas Prima Indonesia Medan, Dosen Pembimbing, SMA Amir Hamzah Medan yang telah memberikan kesempatan dan dukungan sehingga penelitian ini dapat terselesaikan dengan baik.

\section{DAFTAR PUSTAKA}

[1] Prasetyo Ekkal. 2016. Rancang Bangun Ujian Saringan Masuk Pada Sekolah Tinggi Ilmu Ekonomi (STIE) Rahmaniya Sekayu. Jurnal Teknik Informatika Politeknik Sekayu (TIPS).5(1):1-9.

[2] Utomo Prasetya Ridwan, Budiman Arief, Triono Joko.2017. Aplikasi Ujian Online Masuk Universitas Merdeka Madiun Berbasis Android.Jurnal Ilmiah Ilmu-Ilmu Teknik.2(1).

[3] Jannah Nurul Erliyah, Bayturohman. K.D, Kurniawan Endang.2017. Pengembangan Aplikasi Penerimaan mahasiswa baru Berbasis Android Dilengkapi dengan Fitur Push Notification.6(4).

[4] Adhar Deny, Nababan Labuhan. 2016. Perancangan Aplikasi Ujian Saringan Masuk Perguruan Tinggi Secara Online Berbasis Android (Studi Kasus Universitas Potensi Utama Medan). 15(3): 217-223.

[5] Jayanti Mugi, Wiratomo Yogi.2017. Perancangan Media Siap Un Matematika Smp Berbasis Android.Jurnal SAP.2(1).

[6] Anwar.N.S, Nugroho Isworo, Lestariningsi Endang. 2015. Perancangan Dan Implementasi Aplikasi Mobile Semarang Guidance Pada Android.Jurnal Teknologi Informasi DINAMIK.20(1):148-158.

[7] Chandra Fitria.Y,Dwiyani Nurindah,Huda Yasdinul.2016. Perancangan Aplikasi Mobile Learning Test Of English For International Communication (Toeic) Simulation Pada Smartphone Berbasis Android.VOTENIKA.4(2).

[8] Kumar Ashwin L. 2012. Mobile Application for News and Interactive Services.2(1).

[9] Mukherjee Shubhankar, Prakash Jyoti, Kumar Deepak.2015. Android Application Development \& Its Security.4(3):714-719.

[10] Kosidin, Farizah Nur Resha. 2016. Pemodelan Aplikasi Mobile Reminder Berbasis
Android.Seminar Nasional Teknologi informasi dan Komunikasi.

[11] Weng Sheng- Ting, Hsu Hui- Meng, and Yang Ching- Der. 2017. Developing an Online Examination APP System. International Journal of Information and Education Technology.7(8).

[12] Kusniyati Harni, Sitanggang.P.S.N. 2016. Aplikasi Edukasi Toba Samosir Berbasis Android. Jurnal Teknik Informatika.9(1): 918.

[13] Priati, Rerung Rante Rintho. 2017. Sistem Ujian Saringan Masuk Perguruan Tinggi Berbasis Android. Seminar Nasional Teknologi Informasi dan Komunikasi.

[14] Dewi Amalya Meta, Cahyadi Dede, Wulansari Yunita. 2014. Sistem Ujian Online Calon Mahasiswa Baru Berbasis Ilearning Education Marketing Pada Perguruan Tinggi. 8(1).

[15] Supardi yuniar. 2017. Koleksi Program Tugas Akhir dan Skripsi dengan Android. Jakarta: PT.Elex Media komputindo.

[16] Lengkong Nugraha Hendra, sinsuw A.E Alicia, Lumenta S.M Arie.2015. Perancangan Penunjuk Rute Pada Kendaraan Pribadi Menggunakan Aplikasi Mobile GIS Berbasis Android Yang Terintegrasi Pada Google Maps. E-journal Teknik Elektro dan Komputer.

[17] Jubilee Enterprise. 2015. Mengenal DasarDasar Pemograman Android.

[18] Kumar Ashwin L. 2012. Mobile Application for News and Interactive Services. ARPN Journal of Science and Thecnology.2(1).

[19] M. D. Batubara dan E. Indra, "Perencanaan dan Pembuatan Aplikasi Pengerjaan Ujian Nasional Tingkat SMP Berbasis Android," Query: Jurnal Sistem Informasi, vol. 02, no. 02, p. 11, 2018. 